\title{
Genetic variability and association between oil and economic traits for some new Egyptian cotton genotypes
}

\author{
Sara E. I. Eldessouky ${ }^{1 *}$ D, A. B. A. El-Fesheikawy ${ }^{2}$ and K. M. A. Baker ${ }^{2}$
}

\begin{abstract}
Background: Cotton breeding programs mainly focus on improving cotton fibers, but less attention has been paid by breeders to cottonseed oil improvement. Breeding cottonseed for oil content has mainly depended on phenotypic information used to select varieties with high seed oil content. The purpose of this study was to evaluate some cotton genotypes regarding their oil content and other characters related to fiber yield, in order to select genotypes with high oil content and acceptable levels of the other characters. Seventeen different genotypes of cotton were used in this study. A two-year experiment was carried out at Sids Agricultural Research Station, Beni Suef, Egypt, during 2017 and 2018, using a randomized complete block design with six replications. Seed cotton yield, lint cotton yield, boll weight, seed index, embryo index, oil \% and embryo oil index characters were recorded.

Results: The analysis of variance results showed highly significant differences among the genotypes for all the studied traits except boll weight in season 2017. The overall cotton embryo oil \% ranged from 33.40 to 40.28 among the genotypes, while the overall cotton embryo oil index ranged from 1.79 to 2.47 . Maximum cotton embryo oil \% was noted by the genotypes $15[\{(G 83 \times \mathrm{G} 80) \times \mathrm{G} 89\} \times$ Australian $]$ and $8[(\mathrm{G} 91 \times \mathrm{G} 90) \times(\mathrm{G} 85 \times \mathrm{G}$ 83)], while maximum cotton embryo oil index was noted by the genotype $13[(\mathrm{G} 91 \times \mathrm{G} 90) \times \mathrm{G} 80]$. The results showed positive correlations between seed cotton yield and lint cotton yield, seed index and embryo index, seed index and embryo index oil \%, embryo index and embryo index oil \%, and oil \% and embryo index oil \%.

Conclusions: It could be concluded that using seed or embryo oil percentages as criteria for differentiating genotypes according to their oil content is misleading and the best efficient measure is using the seed or embryo oil indices because they depend on weight basis. Also, Genotypes 13, 15 and 8 were the best genotypes regarding oil \% and they could be used in breeding programs for cotton oil improvement.
\end{abstract}

Keywords: Cotton, Oil, Embryo oil, Evaluation

\section{Background}

Cotton is of great economic importance due to textile industry, but cotton seed is an important by-product of processing, since it is the second main source of vegetable oil worldwide (Ashokkumar and Ravikesavan 2008). Cottonseed oil has several applications in the food,

\footnotetext{
*Correspondence: seldessouky@yahoo.com

1 Genetics and Cytology Department, Genetic Engineering

and Biotechnology Research Division, National Research Centre (NRC), PO

Box 12622, Dokki, Cairo, Egypt

Full list of author information is available at the end of the article
}

cosmetic and pharmaceutical sectors. It is also widely used as edible oil and raw material for biodiesel. Basically, cotton breeders are focusing on improving the fiber quality which goes into the textile industry, but less attention has been paid by breeders to cottonseed oil improvement. The cottonseed remaining after capturing value from cotton fiber is most often used as a by-product for cattle feed, fertilizer, cooking oil and numerous industrial applications (Campbell and Hinze 2010).

Cotton breeders are making great efforts to change the traditional breeding programs, which only focus on 
improving fiber characters, by switching for programs including improvement in fiber and cottonseed; subsequently, they will maximize the value of the cotton crop. In the meantime, this will maximize return on investments and encourage the farmers to grow cotton crop. In addition, Chesterfield et al. (2013) reported that cotton crop has attracted more attention as a possibility of using it as a biofuel crop. However, information on the genetic basis of cottonseed oil and protein contents is lacking (Jiwen et al. 2012). Various breeding procedures have been employed with different levels of success for improving the quantity and quality of cottonseed oil content, (Cherry et al. 1981; Dani 1990). Many varieties of cotton have been developed with improved crop yield and productivity (Calhoun and Bowman 1999). Phenotypic information is considered the main method to select cotton genotypes having high seed oil content, in cotton breeding program for high oil content (Pahlavni et al. 2008). The availability of genetic variation affects the outcome of a breeding program (Silveira 2007). Dani (1991) and Khan et al. (2009) showed significant variation in oil contents in cotton. The genetic variability for oil content in cotton is widely reported in the literature (Carvalho et al. 2017). Regarding the correlation between oil content and fiber quality or yield characters, there are many reports ranging from the absence of correlation to high correlations, with reduced repeatability of the correlations (Mert et al. 2005; Badigannavar and Myers 2015). According to the research of Doman et al. (1982), the oil mainly accumulates in embryo of cotton seed and accounts for approximately $80 \%$ of the dry weight of the mature cotton embryo. The linter would lower the yield of oil due to absorption of the oil by the cellulose fibers. Therefore, the linter and hull should be removed before oil extraction to obtain high quality of oil. Compared with cottonseed oil contents, embryo oil contents would be more precise to the oil production (Chen et al. 2015). Until recently, the oil accumulation in cotton embryo has been relatively neglected as the main research priority has been devoted to cottonseed.

The objective of this work was to evaluate some of Egyptian cotton genotypes for the oil content and characters related to fiber yield, in order to select genotypes with high oil content and acceptable levels of the other characters.

\section{Methods}

\section{Plant material}

Seventeen different genotypes of cotton (Gossypium barbadense L.) were used in this study: 13 new cotton lines, as well as two checks and two commercial varieties from cotton breeding programs of Cotton Research Institute,
ARC, Egypt. The code and pedigree of these genotypes are presented in Table 1.

\section{Experimental design and field procedures}

A two-year experiment was carried out at Sids Agricultural Research Station, Beni Suef, Egypt $\left(118^{\circ} 50^{\prime} \mathrm{E}, 32^{\circ}\right.$ $02^{\prime} \mathrm{N}$ ) in 2017 and 2018. The experimental design was a randomized complete block design with four replications. Plot size was five rows, and each row is $4 \mathrm{~m}$ long $\times 0.6 \mathrm{~m}$ wide and $20 \mathrm{~cm}$ between hills within rows with two plants/hill (40 plants per row). All recommended cultural practices and inputs including fertilizer, hoeing, irrigation and pest control were applied same for all the genotypes from sowing till the harvesting. The three central rows of each plot at each location were hand picking to determine seed and lint cotton yield in kentar/feddan. A random sample of 50 bolls was picked from the two outer rows per plot to determine boll weight and lint percentage. The following characters were recorded for each genotype: (1) total seed cotton yield (Scy $(\mathrm{k} / \mathrm{f}))$, (2) lint cotton yield (Lcy $(\mathrm{k} / \mathrm{f})$ ), (3) boll weight (BW (g)): average weight of 50 sound open bolls, (5) seed index (SI (g)): weight of 100 seeds, (6) embryo index (EI (g)): weight of embryo in 100 seeds.

\section{Oil analysis}

After ginning the seeds, seed samples were acid-delinted and were oven-dried at $40{ }^{\circ} \mathrm{C}$ for $24 \mathrm{~h}$. Cottonseed hull was slightly cracked with a nutcracker before being

\section{Table 1 Code and pedigree of the cotton genotypes}

\begin{tabular}{|c|c|c|}
\hline Code & Genotype & Definition \\
\hline 1 & CB $58 \times($ G $91 \times$ G 90) & Cotton line \\
\hline 2 & $(\mathrm{G} 85 \times \mathrm{G} 83) \times\{\mathrm{G} 83 \times(\mathrm{G} 75 \times 5844)\}$ & Cotton line \\
\hline 3 & $(\mathrm{G} 90 \times$ Australian $) \times \mathrm{G} 85$ & Cotton line \\
\hline 4 & $\begin{array}{l}(\mathrm{G} 90 \times \text { Australian })) \times\{(\mathrm{G} 83 \times \mathrm{G} 72) \times \text { Dan- } \\
\quad \text { dara }\}\end{array}$ & Cotton line \\
\hline 5 & $\{(\mathrm{G} 83 \times \mathrm{G} 80) \times \mathrm{G} 89\} \times\{\mathrm{G} 83 \times(\mathrm{G} 75 \times 5844)\}$ & Cotton line \\
\hline 6 & $(\mathrm{G} 91 \times \mathrm{G} 90) \times \mathrm{G} 85$ & Cotton line \\
\hline 7 & $(G 91 \times G 90) \times\{G 83 \times(G 75 \times 5844)\}$ & Cotton line \\
\hline 8 & $(\mathrm{G} 91 \times \mathrm{G} 90) \times(\mathrm{G} 85 \times \mathrm{G} 83)$ & Cotton line \\
\hline 9 & $(\mathrm{G} 91 \times \mathrm{G} 90) \times\{(\mathrm{G} 83 \times \mathrm{G} 80) \times \mathrm{G} 89\}$ & Cotton line \\
\hline 10 & $(\mathrm{G} 90 \times$ Australian $) \times\{\mathrm{G} 83 \times(\mathrm{G} 75 \times 5844)\}$ & Cotton line \\
\hline 11 & $(\mathrm{G} 91$ × G90) × Karashinky & Cotton line \\
\hline 12 & $\begin{array}{l}\{(\mathrm{G} 83 \times \mathrm{G} 80) \times \text { Dandara }\} \times(\mathrm{G} 90 \times \text { Austral }- \\
\quad \text { ian })\end{array}$ & Cotton line \\
\hline 13 & $(\mathrm{G} 91 \times \mathrm{G} 90) \times \mathrm{G} 80$ & Cotton line \\
\hline 14 & CB $58 \times$ G90 & Check \\
\hline 15 & $\{(\mathrm{G} 83 \times \mathrm{G} 80) \times \mathrm{G} 89\} \times$ Australian & Check \\
\hline 16 & Giza 95 & Commercial variety \\
\hline 17 & Giza 90 & Commercial variety \\
\hline
\end{tabular}


manually removed and separated from the embryo. Embryo oil content was measured with Soxhlet extraction (Luque De Castro and Garcia-Ayuso 1998). The use of percentages to characterize cottonseed composition can be misleading, especially when seed weight changes. For this reason, the embryo oil index was computed to express compositions as weight rather than percentages. Oil content was expressed as a percentage of embryo weight (embryo oil percentage (EO (\%)) and weight (mg) per embryo (embryo oil index (EOI)).

Embryo oil index (weight of oil in 100 embryo $)=$ embryo oil $\% \times$ acid-delinted seed index $/ 100$.

\section{Statistical analyses}

All the recorded data were subjected to analysis of variance (ANOVA) technique for a RCB design as outlined by Steel and Torrie (1980) for all the traits to test the null hypothesis of no differences among the cotton genotypes. Plot means were used for statistical analysis. Bartlett's test for heterogeneity of error variance indicated that error terms were nonhomogeneous. Thus, each year's data are presented separately. The genotypes means for each parameter were further separated and compared by using the least significant difference (LSD) test at 5\% level of probability. The simple correlation coefficient $(r)$ of seed cotton yield with other seed and oil traits was also worked out according to Kwon and Torrie (1964).

Mean product expectations of the covariance analysis are analogous to the mean square expectations for the analysis of variance. Thus, estimates of the genotypic covariance component between two traits $\left(\operatorname{Cov} g_{i j}\right)$ and the phenotypic covariance component between two traits
$\left(\operatorname{Cov} p_{i j}\right)$ were derived in the same fashion as for the corresponding variance components (Miller et al. 1958).

The variance components and covariance components were used to compute phenotypic $\left(r_{\mathrm{p}}\right)$ correlation coefficients on a line mean basis, between yield and yield components and oil seed cotton traits as follows:

$$
r_{\mathrm{p}}=\frac{\operatorname{Cov} p_{i j}}{\left[\left(\delta^{2} p_{i}\right) \times\left(\delta^{2} p_{j}\right)\right]^{1 / 2}}
$$

where $\operatorname{Cov} p_{i j}$ is the phenotypic covariance between the two traits, $\left[\left(\delta^{2} p_{i}\right) \times\left(\delta^{2} p_{j}\right)\right]^{1 / 2}$ is the square root of the phenotypic variance of trait $i$ and trait $j$.

\section{Results and discussion}

According to analysis of variance (Table 2), genotypes revealed highly significant differences $(p \leq 0.01)$ for all the studied traits except boll weight in season 2017. This indicated that genotypes differ in their genetic potentials for these traits. These results are in line with those of previous cotton breeders who reported significant variability among Egyptian germplasm in cottonseed oil content and associated traits (Abo El-Zahab et al. 1992, 2003; Carvalho et al. 2017).

\section{Seed cotton yield (SCY) and lint cotton yield (LCY)}

Overall lint cotton yield ranged from 9.29 to 13.83 for season 2017, and it ranged from 7.87 to 12.41 for season 2018 among the 17 genotypes. Maximum lint cotton yield was observed by genotypes 6 and 4 for season 2017 and by genotypes 1, 10 and 6 for season 2018. Lowest lint cotton yield was gained by genotype 17 for both of the seasons. Overall seed cotton yield ranged from 7.48

Table 2 Mean squares for analysis of variance across two seasons of cotton genotypes for yield and oil characters

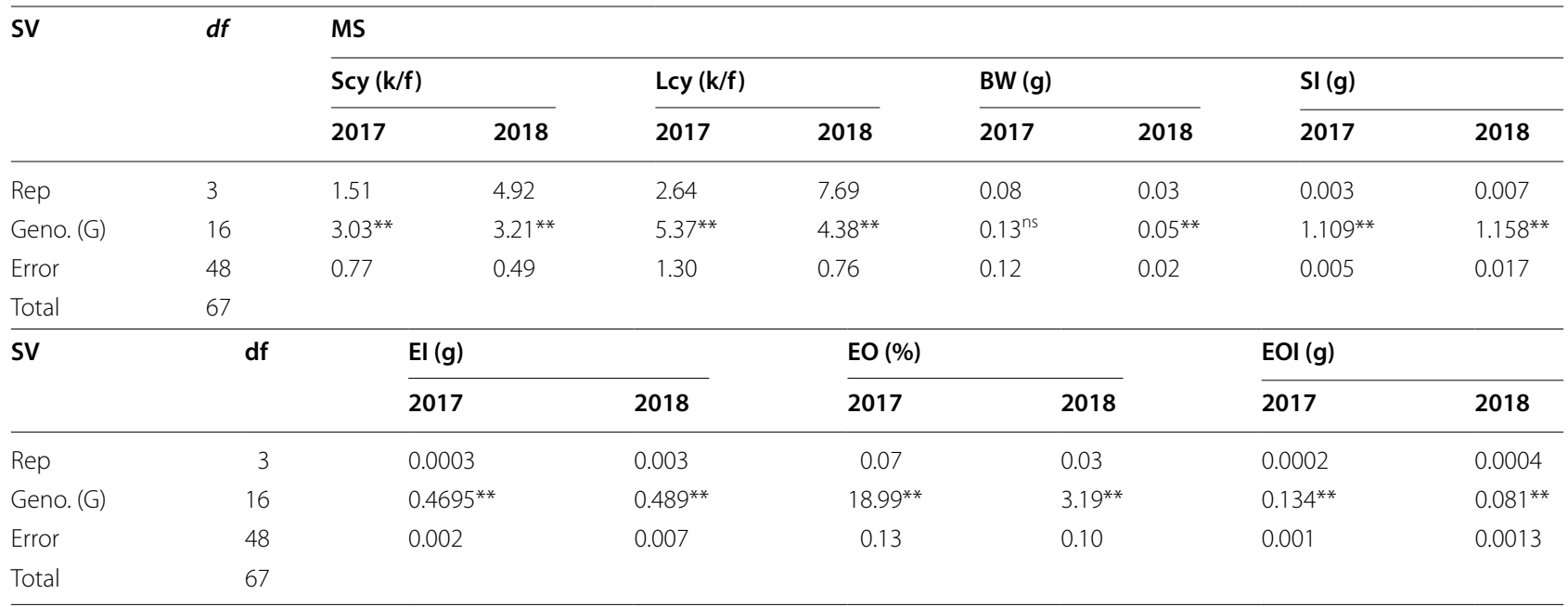

Scy seed cotton yield (k/f), Lcy lint cotton yield (k/f), BW boll weight (g), S/ seed index (g), El embryo index (g), EO embryo oil percentage (\%), EOl embryo oil index (g) ns and ** Non significant and Significant differences at 0.01 levels of probability, respectively 
to 10.59 for season 2017, and it ranged from 6.16 to 9.87 for season 2018 among the 17 genotypes. Maximum seed cotton yield was observed by genotypes $6,4,16$ and 1 for season 2017 and by genotypes 1, 10, 6 and 16 in 2018 . Lowest seed cotton yield was gained by genotype 17 for both of the seasons.

Seed cotton yield is an ultimate goal in growing cotton besides lint cotton yield (Khan et al. 2010). For season 2017, highest seed cotton yield was observed by genotypes 6 and 4 followed by 16, 1, 14 and 12. They also found as the top-scoring genotypes for LCY, and genotypes 6 and 12 were also found as the first and second top-scoring genotypes for cotton embryo oil \% and index (Table 3).

For season 2018, highest seed cotton yield was observed by genotypes 1,10 and 6 followed by 16 and 4 . They were also found as the top-scoring genotypes for LCY, and genotype 1 was also found as the first top-scoring genotype for cotton embryo oil \% and index (Table 3 ).

Correlation was found positive and highly significant $(r=0.96$ and $r=0.99)$ between lint cotton yield and seed cotton yield for seasons 2017 and 2018, respectively (Table 4).

Same variability for seed cotton yield was also reported by Arshad et al., (1993), and Cook and El-Zik (1993). It revealed that the seed cotton yield was mainly controlled by genetic variance. Rao and Mary (1996) studied upland cotton genotypes and found high genetic variability in seed cotton yield. Ahmad et al. (2008) evaluated different G. hirsutum cultivars for yield and other economic characters and observed significant variations for seed traits and positive effect on yield. Ahmad et al. (2008) reported significant correlations, which indicated that any improvement in seed traits would have a positive effect on seed cotton yield. Khan et al. (2007) and Soomro et al. (2008) also mentioned that seed cotton yield was significantly positively correlated with seed traits.

\section{Boll weight}

Overall boll weight of 17 genotypes ranged from 2.47 to 3.21 for season 2017, and it ranged from 2.85 to 3.38 for season 2018 (Table 3). However, the highest boll weight was obtained by genotypes 3 and 4 for season 2017, and it was noted by genotypes 15, 2, 14, 13 and 3 for season 2018. Minimum value of boll weight was obtained by genotype 16 for season 2017, and it was noted by genotype 1 for season 2018. For season 2017, the correlation was negative and nonsignificant ( $r=-0.24$ and $r=-0.27$ ) for the boll weight with lint and seed cotton yield, respectively (Table 4). For season 2018, the correlation was

Table 3 Mean performance of cotton genotypes for yield and oil characters across two seasons

\begin{tabular}{|c|c|c|c|c|c|c|c|c|c|c|c|c|c|c|}
\hline \multirow[t]{3}{*}{ Genotype } & \multicolumn{14}{|c|}{ Means } \\
\hline & \multicolumn{2}{|c|}{ Scy $(k / f)$} & \multicolumn{2}{|c|}{$\operatorname{Lcy}(k / f)$} & \multicolumn{2}{|c|}{$\mathrm{BW}(\mathrm{g})$} & \multicolumn{2}{|l|}{ SI (g) } & \multicolumn{2}{|l|}{ El $(g)$} & \multicolumn{2}{|l|}{ EO (\%) } & \multicolumn{2}{|c|}{ EOI (g) } \\
\hline & 2017 & 2018 & 2017 & 2018 & 2017 & 2018 & 2017 & 2018 & 2017 & 2018 & 2017 & 2018 & 2017 & 2018 \\
\hline 1 & 9.72 & 9.87 & 12.27 & 12.41 & 2.85 & 2.85 & 9.66 & 9.78 & 6.29 & 6.35 & 35.99 & 38.02 & 2.26 & 2.42 \\
\hline 2 & 8.79 & 8.11 & 11.23 & 10.37 & 2.91 & 3.18 & 8.88 & 9.04 & 5.77 & 5.88 & 33.99 & 37.26 & 1.96 & 2.19 \\
\hline 3 & 8.45 & 8.81 & 10.65 & 11.17 & 3.21 & 3.16 & 8.08 & 8.19 & 5.25 & 5.33 & 34.07 & 36.56 & 1.79 & 1.95 \\
\hline 4 & 10.20 & 9.22 & 12.93 & 11.56 & 3.20 & 3.09 & 9.01 & 9.14 & 5.85 & 5.94 & 33.77 & 36.47 & 1.98 & 2.17 \\
\hline 5 & 9.14 & 8.87 & 11.55 & 11.10 & 2.97 & 2.98 & 9.95 & 10.11 & 6.47 & 6.57 & 33.40 & 36.56 & 2.16 & 2.40 \\
\hline 6 & 10.59 & 9.59 & 13.83 & 12.13 & 3.01 & 3.07 & 9.69 & 9.63 & 6.30 & 6.26 & 39.14 & 37.25 & 2.46 & 2.33 \\
\hline 7 & 9.14 & 9.29 & 11.62 & 11.40 & 3.03 & 3.08 & 8.72 & 8.67 & 5.67 & 5.64 & 38.39 & 36.59 & 2.18 & 2.06 \\
\hline 8 & 9.44 & 8.32 & 11.82 & 10.29 & 3.03 & 3.11 & 8.96 & 9.00 & 5.82 & 5.85 & 38.79 & 39.25 & 2.26 & 2.29 \\
\hline 9 & 8.50 & 8.89 & 10.35 & 11.01 & 3.07 & 3.04 & 8.50 & 8.45 & 5.52 & 5.49 & 38.40 & 37.36 & 2.12 & 2.05 \\
\hline 10 & 9.27 & 9.81 & 11.91 & 12.15 & 3.19 & 3.01 & 9.57 & 9.47 & 6.22 & 6.15 & 39.31 & 37.05 & 2.45 & 2.28 \\
\hline 11 & 8.05 & 8.55 & 10.29 & 10.76 & 3.07 & 3.05 & 9.24 & 9.32 & 6.01 & 6.06 & 36.92 & 38.03 & 2.22 & 2.30 \\
\hline 12 & 9.70 & 9.19 & 12.64 & 11.26 & 2.87 & 2.99 & 9.26 & 9.10 & 6.02 & 5.91 & 39.10 & 35.31 & 2.35 & 2.09 \\
\hline 13 & 9.33 & 9.13 & 12.15 & 11.16 & 3.10 & 3.16 & 10.00 & 10.03 & 6.50 & 6.52 & 38.09 & 37.49 & 2.47 & 2.44 \\
\hline 14 & 9.70 & 7.95 & 12.66 & 9.98 & 3.08 & 3.16 & 9.38 & 9.36 & 6.10 & 6.08 & 36.69 & 36.40 & 2.24 & 2.21 \\
\hline 15 & 7.61 & 8.06 & 10.59 & 10.49 & 3.15 & 3.38 & 8.76 & 8.65 & 5.69 & 5.62 & 40.28 & 37.96 & 2.29 & 2.13 \\
\hline 16 & 9.84 & 9.38 & 12.64 & 11.51 & 2.47 & 3.07 & 9.25 & 9.27 & 6.01 & 6.03 & 37.53 & 37.94 & 2.26 & 2.29 \\
\hline 17 & 7.48 & 6.16 & 9.29 & 7.87 & 2.99 & 3.14 & 9.68 & 9.71 & 6.29 & 6.31 & 36.53 & 37.02 & 2.30 & 2.34 \\
\hline $\mathrm{LSD}_{0.05}$ & 1.04 & 0.83 & 1.35 & 1.03 & ns & 0.15 & 0.08 & 0.15 & 0.05 & 0.10 & 0.43 & 0.38 & 0.03 & 0.04 \\
\hline $\mathrm{LSD}_{0.01}$ & 1.49 & 1.19 & 1.93 & 1.48 & NS & 0.22 & 0.12 & 0.22 & 0.08 & 0.14 & 0.62 & 0.55 & 0.05 & 0.06 \\
\hline
\end{tabular}


Table 4 Phenotypic $\left(r_{p}\right)$ correlation coefficients among all studied traits of cotton genotypes across two seasons

\begin{tabular}{|c|c|c|c|c|c|c|}
\hline & $\operatorname{LCY}(\mathbf{k} / \mathbf{f})$ & BW (g) & SI (g) & $\mathrm{EI}(\mathrm{g})$ & $\mathrm{EO} \%$ & EOI (g) \\
\hline \multirow[t]{2}{*}{$\operatorname{SCY}(k / f)$} & $0.96^{* *}$ & -0.27 & 0.3 & 0.31 & -0.01 & 0.21 \\
\hline & $0.99^{* *}$ & $(-0.54)^{*}$ & 0.04 & 0.0 .04 & -0.06 & 0.02 \\
\hline \multirow[t]{2}{*}{$\operatorname{LCY}(\mathrm{k} / \mathrm{f})$} & & -0.24 & 0.33 & 0.33 & 0.1 & 0.3 \\
\hline & & $\left(-0.49^{*}\right)$ & 0.02 & 0.02 & -0.04 & 0.01 \\
\hline \multirow[t]{2}{*}{ BW (g) } & & & -0.23 & -0.23 & -0.01 & -0.16 \\
\hline & & & -0.38 & -0.38 & 0.12 & -0.31 \\
\hline \multirow[t]{2}{*}{ SI (g) } & & & & $1.00^{* *}$ & 0.04 & $0.71^{* *}$ \\
\hline & & & & $1.00^{* *}$ & 0.04 & $0.93^{* *}$ \\
\hline \multirow[t]{2}{*}{$\mathrm{El}(\mathrm{g})$} & & & & & 0.04 & $0.71^{* *}$ \\
\hline & & & & & 0.04 & $0.93^{* *}$ \\
\hline \multirow[t]{2}{*}{ EO (\%) } & & & & & & $0.73^{* *}$ \\
\hline & & & & & & 0.41 \\
\hline
\end{tabular}

Scy seed cotton yield (k/f), Lcy lint cotton yield (k/f), BW boll weight (g), S/ seed index (g), El embryo index (g), EO embryo oil percentage (\%), EOl embryo oil index (g)

* ${ }^{* *}$ Significant differences at 0.05 and 0.01 levels of probability, respectively

negative and significant $(r=-0.49$ and -0.54$)$ with lint and seed cotton yield, respectively (Table 4).

The results are not on line with those reported by Iqbal et al. (2003), Ahmad et al. (2008) and Khan et al. (2010).

\section{Seed index (SI) and embryo index (EI)}

Maximum seed and embryo index were noted by genotypes 5 and 13 for season 2017 and by the same genotypes for season 2018 (Table 3). However, genotypes 7, 9 and 15 manifested the lowest seed and embryo index for both of the seasons. All the remaining genotypes showed medium values of seed and embryo index.

The correlation was positive and highly significant $(r=1.00)$ between seed and embryo index for both of the seasons. Also, they showed positive and highly significant correlation ( $r=0.71$ and $r=0.93)$ with cotton embryo oil \% and index for both of the seasons, respectively (Table 4).

Embryo weight was directly related to seed weight (Black 1956). Seed and embryo index traits are also an important yield factors and play an imperative role in increasing seed cotton yield and cottonseed oil \% (Khan et al. 2010). Seed index had a positive correlation with seed and lint yield traits. Dani (1991) studied the mean performance of G. hirsutum for seed index and observed significant variations among cultivars for seed index. Suinaga et al. (2006) and Meena et al. (2007) studied the yielding capacity of $G$. hirsutum cultivars and observed varied values for seed index. Hassan et al. (2005) studied the performance of Egyptian cotton cultivars and found a positive and significant correlation between seed index and seed cotton yield. Iqbal et al. (2003) mentioned in their studies conducted on G. hirsutum for seed index, yield and other yield-related traits and observed that yield attributes also varied significantly among cultivars.

\section{Cotton embryo oil \%}

The overall cotton embryo oil \% ranged from 33.40 to $40.28 \%$ for season 2017 and from 35.31 to 39.25 for season 2018 among 17 cotton genotypes (Table 3). Maximum cotton embryo oil \% was noted by the genotypes 15 for season 2017 and by genotype 8 for season 2018. It was closely followed by genotypes 10,6 and 12 for season 2017 and 11, 1, 15 and 16 for season 2018. However, genotype 5 manifested lowest cotton embryo oil content in season 2017, while genotype 12 manifested lowest cottonseed oil content in season 2018. All the remaining genotypes showed medium values of cotton embryo oil $\%$ for both of the seasons. During the embryo development stage, cultivar characteristic (Ye et al. 2003; Mert et al. 2005), environmental conditions (Kohel and Cherry 1983; Lv et al. 2013) and crop management (Sawan et al. 2006) will influence the embryo growth and consequently the embryo oil contents.

For season 2017, the correlation was positive but nonsignificant $(r=0.10)$ for the embryo oil \% with lint cotton yield, while it was negative but nonsignificant $(r=-0.01)$ with seed cotton yield (Table 4). For season 2018, the correlation was negative but nonsignificant $(r=-0.04$ and -0.06$)$ with lint cotton yield and seed cotton yield, respectively (Table 4). Some studies with cotton (Dani 1991; Erande et al. 2014) reported no correlation between oil content and characters related to yield and fiber quality; others, however, showed significant correlations (Mert et al. 2005; Badigannavar and Myers 2015). Selection for high oil content does not appear to compromise fiber yield and quality (Carvalho et al. 2017). Khan et al. 
(2010) reported that correlation among lint index, lint \% and oil \% is rarely found and ultra-desirable by the cotton breeders and a little genetic gain in seed and lint traits, and oil content is a great accomplishment.

\section{Cotton embryo oil index}

The overall cotton embryo oil index ranged from 1.79 to 2.47 for season 2017 and from 1.95 to 2.44 for season 2018 among 17 cotton genotypes (Table 3). Maximum cotton embryo oil index was noted by the genotype 13 in both seasons. It was closely followed by genotypes 6 and 10 for season 2017 and genotypes 1 and 5 for season 2018. However, genotype 3 manifested lowest cotton embryo oil index in both seasons. All the remaining genotypes showed medium values of cotton embryo oil index (Table 3). For season 2017, the correlation was positive but nonsignificant $(r=0.30$ and $r=0.21$ ) for the embryo oil index with lint cotton yield and seed cotton yield, respectively (Table 4). For season 2018, the correlation was positive but nonsignificant $(r=0.01$ and 0.02$)$ with lint cotton yield and seed cotton yield, respectively (Table 4).

Fairly clear-cut differences among genotypes for seed or embryo oil content were found when oil content was expressed in the form of embryo percentage or index (embryo oil index), whereas overlapping between genotypes differences was found when seed oil content was expressed as percentage of embryo. Therefore, more emphasis must be directed toward using both percentage and index in differentiating among genotypes (Abo ElZahab et al. 2003).

The contrast characterizing between cotton embryo oil composition as percentage (embryo oil percentage) or on weight basis (embryo oil index, g/100 embryos) is obvious via comparing the mean performance of genotype 6 versus genotype 12 for season 2017 for these two traits (Table 3). Both genotypes exhibited significantly the same oil percentage mean performance (genotype $6=39.14 \%$ and genotype $12=39.10 \%$ ), where they were significantly different in embryo oil index (genotype $6=2.46$ ranked first compared to genotype $12=2.35$ ).

For 2017, this difference in genotype rating in seed oil index may be due to differences in seed and embryo indices where genotype 6 showed $9.69 \mathrm{~g} / 100$ seed and $6.30 \mathrm{~g} / 100$ embryo, respectively, that exceeded genotype 12 (9.26 g/100 seed and $6.02 \mathrm{~g} / 100$ embryo, respectively). Even genotype 10 has higher oil percentage (39.31\%) than genotype 6 but it has less embryo oil index (2.45) and lesser seed and embryo indices $(9.57 \mathrm{~g} / 100$ seed and $6.22 \mathrm{~g} / 100$ embryo, respectively) as shown in Table 3. Also, the contrast characterizing is obvious in the second season via comparing the mean performance of genotype 1 versus genotype 11 for these two traits; both genotypes exhibited the same oil percentage (G.1 $=38.02 \%$ and G.11 $=38.03 \%$ ), where they were significantly different in embryo oil index G.1 (2.42) was ranked first compared to G.11 (2.30).

This difference in genotype rating in seed oil index may be due to differences in seed and embryo indices where G.1 (9.78 g/100 seed and $6.35 \mathrm{~g} / 100$ embryo) exceeded the G.11 (9.32 g/100 seed and $6.06 \mathrm{~g} / 100$ embryo) as shown in Table 3.

Genotypes 1, 6 and 13 expressed the highest mean values for oil in cotton seed expressed as percentage or index in embryo.

Therefore, using seed or embryo oil percentages as criteria for differentiating among genotypes in their content of oil is misleading and the best efficient measure is using the seed or embryo oil indices because they depend on weight basis. Similar conclusions were reached by Abo El-Zahab et al. (1992, 2003). In this connection, in Upland cotton, Dani (1984) found highly significant positive correlations between seed size and seed oil index, although the percentage of seed oil itself was not always significantly associated with both seed size and seed oil index. Thus, seed oil index seems to be important in selection for seed oil in cotton. Kohel and Cherry (1983) concluded that the use of percentages to characterize cottonseed composition can be misleading, especially when seed weights change. For this reason, the seed oil index was recommended to express compositions as weights rather than percentages. Kohel (1980) found that the use of seed oil percentage as the only measure of seed oil content could result in selection of embryo percentage at the expense of the seed coat. However, the use of seed index as a measure of seed oil favored selection for seed size.

Hassan et al's (2005) studies exhibited the performance of Egyptian cotton cultivars for cottonseed oil \% and found significant mean differences. Kohel (1980) also investigated the inheritance of cottonseed oil \% and exhibited significant variability for cottonseed oil $\%$ and the heritability based on parental cultivars ranging from 42 to $66 \%$. Hossain (1983) studied mean performance and heritability of cottonseed oil and yield in two pureline cultivars and their hybrids of upland cotton and observed that high oil content was a continuously varying character, which differentiated the parents into relatively high and low oil types and the heritability was moderate (42\%) for cottonseed oil \%. Dani (1991) studied the mean performance of G. hirsutum cultivars for cottonseed oil $\%$ and observed significant variations among genotypes. Great genetic variations among cotton species and cultivars in respect to cottonseed oil (17-27\%) existed (Kohel 1980; Dowd et al. 2010; Bolek et al. 2016). Quampah et al. (2012) revealed the amount of oil inside the seeds ranged 
between 22.68 and $36.83 \%$ and the average amount was $31.42 \%$, while average oil content of genotypes in our study was $37 \%$ which is in accordance with earlier studies (Bolek et al. 2016).

Khan et al. (2009) and Carvalho et al. (2017) observed genetic variability of cottonseed oil \% in the G. hirsutum cultivars. Some of the incompatible views of past researchers about the said trait might be due to genotypic and environmental variations and due to different genetic ambiance of the cultivars used in various environmental conditions.

Phenotypic correlations were calculated to determine the genetic relationships among seed composition traits (oil) and agronomic traits (Table 3). The results showed positive phenotypic correlations between LCY and SCY (0.96 and 0.99), EI and SI (1.00 and 1.00), EI oil and SI (0.71 and 0.93) and EI oil and EI (0.71 and 0.93). In the meantime, there was a positive phenotypic correlation between EI oil and oil \%, while there was a negative genotypic correlation between BW and SCY (-0.54) and also between BW and LCY (-0.49). The results of this study are similar to those reported by other authors (Abo ElZahab et al. 1992, 2003).

\section{Conclusion}

It could be concluded that using seed or embryo oil percentages as criteria for differentiating among genotypes in their content of oil is misleading and the best efficient measure is using the seed or embryo oil indices because they depend on weight basis. Also, genotypes 13,15 and 8 were the best genotypes regarding oil \% and they could be used in breeding programs for cotton oil improvement.

\section{Abbreviations \\ Scy: Seed cotton yield (k/f); Lcy: Lint cotton yield (k/f); BW: Boll weight (g); SI: Seed index (g); El: Embryo index (g); EO: Embryo oil percentage (\%); EOl: Embryo oil index (g.}

\section{Acknowledgements}

The authors would like to acknowledge Cotton Research Institute, ARC, Egypt, for providing the plant materials for the present research.

\section{Authors' contributions}

This work was carried out in collaboration between all the authors. A.B.A.E. and K.M.A.B. conducted the field experiments and the statistical analysis, and S.E.I.E. conducted the oil analysis and wrote the manuscript. All authors read and approved the final manuscript for publication.

\section{Funding}

Not applicable.

\section{Availability of data and materials}

The datasets used and/or analyzed during the current study are available from the authors on reasonable request.

\section{Ethics approval and consent to participate}

Not applicable.
Consent for publication

Not applicable.

\section{Competing interests}

The authors declare that they have no competing interests.

\section{Author details}

${ }^{1}$ Genetics and Cytology Department, Genetic Engineering and Biotechnology Research Division, National Research Centre (NRC), PO Box 12622, Dokki, Cairo, Egypt. ${ }^{2}$ Cotton Research Institute, Agricultural Research Center, Giza, Egypt.

Received: 23 November 2019 Accepted: 20 October 2020

Published online: 17 February 2021

\section{References}

Abo El-Zahab AA, Saad FF, Abd El-Ghani (1992) Cotton seed oil content in Egyptian cotton germplasm I. Variability and covariability and their implications in cotton breeding. In: Proceedings of the 5th Conference on Agron. Zagazig, 13-15 Sept (2), pp 789-800

Abo El-Zahab AA, Ramadan BSH, Amein MMM, Eldessouky Sara El (2003) Seed quality in Egyptian cotton. III-Co-variability and co-heritability. In: Proceedings of the 10th Conference on Agron, Suez Canal University, 7-10 Oct, Faculty of Environmental Agricultural Sciences, EL-Arish, Egypt, pp 483-502

Ahmad W, Khan NU, Khalil MR, Parveen A, Aimen U, Saeed M, Samiullah R, Shah SA (2008) Genetic variability and correlation analysis in upland cotton. Sarhad J Agric 24:573-580

Arshad M, Hanif M, llahi N, Shah SM (1993) Correlation studies on some commercial cotton varieties of G. hirsutum. Sarhad J Agric 9:49-53

Ashokkumar K, Ravikesavan R (2008) Genetic studies of combining ability estimates for seed oil, seed protein and fiber quality traits in upland cotton (G. hirsutum, L.). Res J Agric Biol Sci 4:798-802

Azhar FM, Ahmad M (2000) Inheritance pattern of cotton seed oil in diverse germplasm of G. hirsutum L. Pak J Biol Sci 3:1250-1252. https://doi. org/10.3923/pjbs.2000.1250.1252

Badigannavar A, Myers GO (2015) Genetic diversity, population structure and marker trait associations for seed quality traits in cotton (Gossypium hirsutum). J Genet 94:87-94. https://doi.org/10.1007/s12041-015-0489-x

Black J (1956) The influence of seed size and depth of sowing on pre-emergence and early vegetative growth of subterranean clover (Trifolium subterraneum L.). Crop Pasture Sci 7:98-109

Bolek Y, Tekerek H, Hayat K, Bardak A (2016) Screening of cotton genotypes for protein content, oil and fatty acid composition. J Agric Sci 8(5):107-121

Calhoun DS, Bowman DT (1999) In: Smith CW, Cothren JT (eds) Cotton origin, history, technology and production. Wiley, New York, pp 361-414

Campbell BT, Hinze LL (2010) Cotton production, processing, and uses of cotton. In: Singh B (ed) Industrial crops and uses. CABI, Wallingford, pp $259-276$

Chen M, Zhao W, Meng Y, Chen B, Wang Y, Zhou Z, Oosterhuis DM (2015) A model for simulating the cotton (Gossypium hirsutum L.) embryo oil and protein accumulation under varying environmental conditions. Field Crops Res 183:79-91

Cherry JP, Kohel RJ, Jones LA, Powell WH (1981) Cotton seed quality: factors affecting feed and food uses. In: Brown JM (ed) Proceedings of the belt wide cotton production research conference. National Cotton Council, Memphis, pp 266-283

Chesterfield M, Rogers PL, Adesina AA (2013) Liquid-liquid phase equilibrium studies of organic-aqueous medium during biodiesel synthesis. Chem Eng Sci 104:540-548. https://doi.org/10.1016/j.ces.2013.09.015

Cook CG, El-Zik KM (1993) Fruiting and lint yield of cotton cultivars under irrigated and non-irrigated conditions. Field Crops Res 33:411-421

Dani RG (1984) Genetic studies of seed-oil development in some cultivars of Gossypium hirsutum L. Seeds Farms 9:25-29

Dani RG (1990) Genetic research of cottonseed oil: a review. Cotton Fibers Trop 45:71-75

Dani RG (1991) Analysis of combining ability for seed oil content in cotton (G. hirsutum). Acta Agron Hung 40:123-127

de Carvalho LP, da Rodrigues JIS, Farias FJC (2017) Selection of cotton lines for high oil content Pesq.agropec. bras. Brasília 52(7):530-538 
Doman DC, Walker JC, Trelease RN, Moore Bd (1982) Metabolism of carbohydrate and lipid reserves in germinated cotton seeds. Planta 155:502-510

Dowd MK, Boykin DL, Meredith WR, Campbell BT, Bourland FM, Gannaway JR, Zhang JF (2010) Fatty acid profiles of cottonseed genotypes from the national cotton variety trials. J Cotton Sci 14:64-73

Erande CS, Kalpande HV, Deosarkar DB, Chavan SK, Patil VS, Deshmukh JD, Chinchane VN, Anil K, Utpal D, Puttawar MR (2014) Genetic variability, correlation and path analysis among different traits in desi cotton (Gossypium hirsutum L.). Afr J Agric Res 9(29):2278-2286

Hassan ISM, Mohamed AS, Abdel-Rahman LMA (2005) Comparative study on seed cotton yield, oil and protein contents in the seed of some Egyptian cotton cultivars grown at different locations. Egypt J Agric Res 83:735-750

Hossain MN (1983) Heritability of oil content of seed, its correlation to seed protein, fiber qualities and yield in cotton (Gossypium hirsutum, L.). Dissertation Abstracts International, B. 44 (3), 666B [En, order No. Da 8317561] Auburn University, Alabama, USA. (C.F. Plant Breed. Abst. 54: 1466)

Iqbal M, Chang MA, lqbal MZ, Hassan MU, Nasir A, Islam NU (2003) Correlation and path coefficient analysis of earliness and agronomic characters of upland cotton in Multan. Pak J Agron 2:160-168

Jiwen Y, Shuxun Y, Shuli F, Meizhen S, Honghong Z, Xingli L, Zhang J (2012) Mapping quantitative trait loci for cottonseed oil, protein and gossypol content in a Gossypium hirsutum × Gossypium barbadense backcross inbred line population. Euphytica 187:191-201. https://doi.org/10.1007/ s10681-012-0630-3

Khan NU, Marwat KB, Hassan G, Farhatukkah S, Batool S, Makhdoom K, Ahamad W, Khan HU (2010) Genetic variation and heritability for cotton seed, fiber and oil traits in Gossypium hirsutum L. Pak J Bot 42:615-625

Khan NU, Hassan G, Kumbhar MB, Parveen A, Aiman U, Ahmad W et al (2007) Gene action of seed traits and oil content in upland cotton (Gossypium hirsutum L.). Sabrao J Breed Genet 39:17-30

Khan NU, Hassan G, Marwat KB, Kumbhar MB, Khan I, Soomro ZA, Kahan MZ (2009) Legacy study of cottonseed traits in upland cotton using Griffing's combining ability model. Pak J Bot 41(1):131-142

Kohel RJ, Cherry JP (1983) Variation of cottonseed quality with stratified harvests. Crop Sci 23:1119-1124. https://doi.org/10.2135/cropsci1983.00111 83X002300060023x

Kohel RJ, Glueck J, Rooney LW (1985) Comparison of cotton germplasm collections for seed protein content. Crop Sci 25:961-963

Kohel RJ (1980) Genetic studies of seed oil in cotton. Crop Sci 20:784-787

Kwon S, Torrie J (1964) Heritability of and interrelationship among traits of two soybean populations. Crop Sci 4:196-198

Luque De Castro MD, Garcia-Ayuso LE (1998) Soxhlet extraction of solid materials: an outdated technique with a promising innovative future. Anal Chim Acta 369:1-10
Lv FJ, Liu JR, Ma YN, Chen J, Abudurezikekey A, Wang YH, Chen BL, Meng YL, Zhou ZG (2013) Effects of shading on cotton yield and quality on different fruiting branches. Crop Sci 53(6):2670-2678

Meena RA, Monga D, Kumar R (2007) Un-descriptive cotton cultivars of north zone: an evaluation. J Cotton Res Dev 21:21-23

Mert M, Akiscan Y, Gencer O (2005) Genotypic and phenotypic relationships of lint yield, fibre properties and seed content in a cross of two cotton genotypes. Acta Agric. Scand Sect B Soil Plant 55:76-80

Miller PA, Williams JC, Comstock RE (1958) Estimates of genotypic and environmental variances and covariances in upland cotton and their implications in selection. Agron J 50:126-131

Pahlavni MH, Miri AA, Kazemi G (2008) Response of oil and protein content to seed size in cotton. Int J Agric Biol 10:643-647

Pettigrew WT, Dowd MK (2011) Varying planting dates or irrigation regimes alters cotton seed composition. Crop Sci 51:2155-2164. https://doi. org/10.2135/cropsci2011.02.0085

Quampah A, Huang R, Wu Z, Liu GJ, Li HY, Zhu JR, Shi CH (2012) Estimation of oil content and fatty acid composition in cotton seed kernel powder using near infrared reflectance spectroscopy. J Am Oil Chem Soc 89:567-575

Rao KVK, Mary TN (1996) Variability, correlation and path analysis of yield and fiber traits in upland cotton. J Res APAU 24:66-70

Sawan ZM, Hafez SA, Basyony AE, Alkassas AR (2006) Cotton seed, protein, oil yields and oil properties as affected by nitrogen fertilization and foliar application of potassium and a plant growth retardant. World J Agric Sci 2:56-65

Silveira GD (2007) Estimates of genetic parameters aimed selection of segregating genotypes of soybeans. Ph.D. thesis in Genetics and Plant Breeding, State University Paulista "Julio de Mesquita Filho", Faculty of Agricultural and Veterinary Sciences UNESP in Jaboticabal, SP, p 45

Soomro ZA, Larik AS, Kumbhar MB, Khan NU, Panhwar NA (2008) Correlation and path analysis in hybrid cotton. Sabrao J Breed Genet 40:49-56

Steel RGD, Torrie JH (1980) Principles and procedures of statistics, a biological approach, 2nd edn. McGraw-Hill, New York

Suinaga FA, Bastos CS, Rangel LEP (2006) Phenotypic adaptability and stability of cotton cultivars in Mato Grosso State. Braz Pesqui Agropecu Trop 36(3):145-150

Ye Z, Lu Z, Zhu J (2003) Genetic analysis for developmental behavior of some seed quality traits in upland cotton (Gossypum hirsutum L.). Euphytica 129:183-191

\section{Publisher's Note}

Springer Nature remains neutral with regard to jurisdictional claims in published maps and institutional affiliations.

\section{Submit your manuscript to a SpringerOpen ${ }^{\odot}$ journal and benefit from:}

- Convenient online submission

- Rigorous peer review

- Open access: articles freely available online

- High visibility within the field

- Retaining the copyright to your article

Submit your next manuscript at $\boldsymbol{\nabla}$ springeropen.com 